\title{
Nurturing Corporate Governance System: The Emerging Trends in Nigeria
}

\author{
Benjamin James Inyang \\ University of Calabar, Nigeria
}

\begin{abstract}
The paper traced the nascent history of corporate governance system in Nigeria and noted the paucity of literature in the subject. Mainstream issues of corporate governance in the country emerged with the enactment of the Companies and Allied Matters Act of 1990 (CAMA 1990), which established the Corporate Affairs Commission (CAC), and charged it with the responsibility of overseeing the regulation and supervision of the formation, incorporation, registration, management and winding up of companies. The corporate governance codes of both the Securities and Exchange Commission (SEC) and the Central Bank of Nigeria (CBN), gave impetus for the development of corporate governance structure, to ensure transparency, accountability, probity, integrity and fairness in the management and control of the public corporations, and thereby creating value for the shareholders and stakeholders. Major challenges which required urgent attention to enhance the effectiveness of the system were noted thus: making the voluntary codes mandatory; developing more effective mechanisms for monitoring compliance and enforcement; developing strong internal control mechanisms to checkmate the boards oversight responsibility; crafting strategies to enhance shareholders activism and the extension of the codes to state-owned enterprises with more cases of corporate governance abuses.
\end{abstract}

\section{Keywords}

Corporate governance; corporate governance system; corporate governance codes; shareholder activism

\section{Introduction}

Corporate governance is a relatively new area of study that is currently attracting increasing interest among a wide spectrum of people - governments, industry operators, directors, investors, stockholders, shareholders, academics, international organisations, etc. In fact, in today's world, corporate governance and its languages - disclosure, transparency, shareholder value and corporate governance are buzzwords in meetings, conferences and roundtables at the World Bank, International Monetary Fund, (IMF) and the Organisation of Economic Co-operation and Development (OECD). These institutions consider informed corporate governance standards as critical in helping emerging markets rebuild competitiveness, restore investor confidence, and promote sustainable economic growth (Reddy, 2001; Koufopoulos, 2006).

Copyright (C) 2009 Victoria University. This document has been published as part of the Journal of Business Systems, Governance and Ethics in both online and print formats. Educational and non-profit institutions are granted a nonexclusive licence to utilise this document in whole or in part for personal or classroom use without fee, provided that correct attribution and citation are made and this copyright statement is reproduced. Any other usage is prohibited without the express permission of the
The different stakeholders to corporate organisations are increasingly demanding to know more about the performance of these public corporations, and asking more pertinent questions about whether the activities of these corporations conform to established standards. Since corporations raised funds from the public to function and operate, they assume an obligation of public trust to act in a manner that protects 
the public interest and make full and fair public disclosure of corporate information, including financial results. This is the basis for corporate governance, and the primary responsibility for ensuring good corporate governance rests squarely with the board of directors and top management of the organisation. According to Elebute (2000. p. 10), "The responsibility for corporate performance, enhancing shareholder value and reliable financial reporting resides first and foremost at the corporate level".

In fact, the directors and top management define the tempo of activities, striving to achieve high quality performance and establishing sound financial reporting system for the organisation.

Several factors have tended to trigger the emerging interest in corporate governance:

a. The separation of ownership from management. The modern corporation has taken an identity of its own, where professional managers are appointed to run the affairs of the corporation. The professional managers constitute a distinct group from the owners, and are supervised in their day-to-day operations of the business by an elected board of directors. This separation of ownership from management creates the justification for defining an appropriate framework that will ensure transparency, accountability, probity, integrity and fairness in the management of the corporation.

b. Current issues of globalization and information communication technology facilitate business transactions across the countries of the world. These developments necessitate the evolution of international business standards to guide business operations across nations and thereby improve corporate performance and to benefit all stakeholders. When corporate governance principles are evolved and international standards are set, investors and creditors' confidence would be enhanced and the regulatory agencies would be sufficiently empowered to handle the monitoring responsibility in their different countries.

c. Corporate failures in recent times in both developed and developing countries have kindled interest in corporate governance. Such well-publicised corporate failures and scandals as: East Asian crises of 1997/98 - for example, Daewoo in South Korea (1998) involving accounting fraud and embezzlement by former CEO; in America the collapse of Enron (2001) involving bankruptcy due to accounting fraud and Worldcom (2002) where the company collapses with US\$41 bn debt due to fraudulent accounting; in United Kingdom the collapse of Marconi (2001) involving bankruptcy due to overprice acquisitions and neglecting of controls; HIH Insurance in Australia (2001) involving stock market manipulations; and Parmalat in Italy (2003) due to undisclosed debts of £14.3bn; Volkswagen in Germany (2005) due to abuse of corporate funds to provide inappropriate benefits (Subramanaya, 2007). In Nigeria we have major cases involving the collapse of the banking sector with 26 banks liquidated in 1997 and the recent financial scandals involving the falsification of the company financial statements in Cadbury Nigeria Plc in 2006 (Olusa, 2007; Amao \& Amaeshi, 2007). All these corporate scandals further raise interest in developing international and national standards on corporate governance, which corporate organisations must adhere to.

This paper presents the mainstream issues in nurturing corporate governance in Nigeria. The paper is divided into five sections. The first section is the introduction while the second section deals with the literature review. The third section traces the evolution of corporate governance in Nigeria. The different roles of key institutions of corporate governance in the country are discussed in section four. The fifth section highlights the challenges facing corporate governance in Nigeria while the last section presents the concluding comments. The paper therefore aims at contributing to and improving on the existing paucity of literature on corporate governance in Nigeria specifically and Africa generally.

\section{Literature Review}

In its simplest conceptualisation, corporate governance refers to the broad range of policy and practices that stockholders, executive managers, and boards of directors use to manage the operations of corporate organisations towards fulfilling their responsibilities to the investors and other stokeholders in 
the society. It is essentially "a system by which the orgnaisation or company directs, manages and controls the business of the company to enhance corporate performance and corporate responsiveness to shareholders and other stakeholders" (Inyang, 2004:163). The basic tenets of good corporate governance are; accountability, efficiency and effectiveness, integrity and fairness, probity, responsibility and transparency. All of these must be considered as imperatives to organisational growth and survival.

Corporate governance is an engaging, fascinating and important subject that has generated a plethora of literature and significant global discourse in the United States of America, Europe and Australia (Kay and Silberston, 1995); Vinten, 1998; 2002; Aquilera and Luervo-Cazurra, 2004; Bhasa, 2004; Mardjono, 2005; Wieland, 2005; Chambers, 2006; Mason, Kirkbride and Bryde, 2007; Hill, 2008; Malin, 2008; Judge, Douglas and Kutan, 2008 and De Cleyn, 2008). Such international organisations like the World Bank, IMF and OECD have in their different ways through workshops, conferences, research studies and policy initiatives contributed immensely to the development of global standards of good corporate governance. See for example (Scott, 2007 and Claessens and Bruno, 2007).

The evolution of corporate governance in Africa is still in its infancy compare to the current state of affairs and the quantum of available literature in the western world. Okeahalam and Akinboade (2003) in a major review confirm the paucity of literature and the very limited rigorous research on corporate governance in Africa. Most of what is currently available in Africa are corporate governance codes of the different countries which were influenced essentially by OECD Principles of Corporate Governance (1999, 2004), the Commonwealth Association for Corporate Governance CACG (1999) and King Reports on Corporate Governance (South Africa, 1994, 2002). The financial scandals around the world and the recent collapse of major corporate institutions in the USA gave the impetus for the development of good corporate governance structure in the emerging economies of Africa. According to Ajogwu (2007. p.2), "The corporate governance structure spells out the rules and procedures for making decisions on corporate affairs [and] provides the structure through which the company objectives are set as well as the means of attaining and monitoring the performance of those objectives. It defines the accountability of those charged with the responsibility of steering the company's affairs". Good corporate governance is therefore the system of managing the affairs of corporations with a view to increasing shareholder value and meeting the expectations of other stakeholders.

Similarly, Aguilera and Cuervo-Cazurra (2004:417-418) consider the codes of good governance as "a set of 'best practice' recommendations regarding the behaviour and structure of the board of directors of a firm ... designed to address deficiencies in the corporate governance system by recommending a comprehensive set of norms on the role and composition of the board of directors, relationship with shareholders and top management, auditing and information disclosure, and selection, remuneration, and dismissal of directors and top managers".

A few existing studies on African corporate governance are limited to single country investigation using case studies. Muranda (2006) investigates the relationship between corporate governance failures and financial distress in Zimbabwe's banking sector. The study found lack of a proactive approach by the regulatory authorities appeared to have encouraged poor corporate governance practices and that the failure by the board of directors to adapt to the demands of a changing competitive environment affected adherence to the principles of good corporate governance. Abor (2001) examines the relationship between corporate governance and capital structure decisions of listed firms in Ghana. The findings show statistically significant and positive associations between capital structure and board size, board composition and CEO duality. Abor and Adjasi (2007) provide conceptual insights on the application of corporate governance among small and medium enterprises (SMEs) in Ghana. The major finding of the study shows that the application of good corporate governance structure among SMEs in Ghana could help overcome credit constraints and managerial incompetence. Rossouw (2000) provides a background to the corporate governance reform in Africa and further analyses the relationship between business ethics and national codes of corporate governance. The study shows that business ethics are considered an integral and essential part of good governance in Africa. In his study of four African countries Ghana, Nigeria, Kenya and South Africa, Kyereboah-Coleman (2001) explores the linkage between 
corporate governance and shareholder value maximization. The findings show that large board sizes enhance corporate performance and shareholder value maximization. Okeahalam and Akinboade's (2003) review of corporate governance in Africa is still a major contribution to this subject. The authors emphasise the need for African nations to learn some lessons from the financial scandals of the western world and East Asian countries, which were attributed essentially to an absence or dereliction of efficient corporate governance. The authors conclude that "The adoption of corporate governance principles by African countries will be a giant step toward creating safeguards against corruption and mismanagement, promote transparency in economic life and attracting more domestic and foreign investment" (p.28).

As it is with Africa generally, corporate governance literature offerings in Nigeria, is scanty. Yakasai (2001) provides some evidence of the evolution of corporate governance in Nigeria within the banking sector. Earlier studies by Okike (1994, 1995, 1998 and 1999) specifically examined the accounting and audit-reporting environment in Nigeria, as important elements of corporate governance. In a recent work, Okike (2007) presents a comprehensive review of corporate governance developments in Nigeria, thus expanding the literature on corporate governance in developing countries. Ahunwan (2002) gives an account of the nature of corporate governance in Nigeria, and extends further, to investigate the prospects for recent reforms of economic liberalization, deregulation and privatization, contributing to more responsible governance. Alo (2003) in a pioneer and edited book presents different perspectives and insights into keys areas of the corporate governance spectrum as valuable contribution to the literature in Nigeria. Nmehielle and Nwauche (2004) examine the corporate governance climate in Nigeria and critically inquires into the external and internal standards that guide Nigerian companies in the way they are governed. Ogbechie and Koufopoulos (2007) evaluate corporate governance issues in public quoted companies in Nigeria. The findings of the study show that Nigeria public companies have embraced the principles of good corporate governance but are at different stages of adoption of various issues that contribute to good corporate governance. Amao and Amaeshi (2008) explore how recent developments in Nigeria contribute to shareholders activism and how to improve participation of shareholders in corporate governance. Ajogwu (2007) presents a comprehensive work on the law and corporate governance practices in Nigeria. The book discusses the legal framework of corporate governance and the institutions that regulate corporate governance practices in Nigeria.

This paper builds on this scanty pioneering literature to expand the horizon of corporate governance in Nigeria noting the mainstream issues, the current reforms and the challenges that have to be overcome to develop a more dynamic and proactive corporate governance system.

\section{Evolution of Corporate Governance in Nigeria}

Corporate governance is of critical importance to a developing country and emerging economy like Nigeria. This is because the institutionalisation of a good corporate governance system will help to "facilitate and stimulate the performance of corporations by creating and maintaining incentives that motivate insiders to maximize the firms' operating efficiency. At the same time it enables the limiting of insiders' abuse of power over corporate, resources, as well as providing the means of monitoring managers' behaviour in order to ensure corporate accountability" (Ogbechie and Koufopoulos, 2007:351).

The provenance of corporate governance system in Nigeria which, involves issues relating to the regulation, control and governance of enterprises can be traced, essentially to Companies and Allied Matters Act (CAMA) 1990, which replaced the Companies Act 1968. This legal framework has its root in the British colonial legislation. In effect, the Nigerian legal system and corporate governance practices mirrored the United Kingdom (UK) pattern (Okika, 2007).

The UK legislations were reviewed when Nigeria attained political independence from Britain in 1960. The Companies Ordinance of 1922 was repealed and replaced by the Companies Act of 1968 (CA). The CA of 1968 was, of course, a replica of UK Companies Act of 1948. The reason for this development was because before the introduction of the indigenisation programme of the government in 1972, the 
British nationals controlled the major business enterprises in the country, and to protect their economic interests they had to bring in their company legislation. This mimicking of the UK's Companies Act in Nigeria failed to accommodate the economic interests and development aspirations of the country. The government in 1972 promulgated the Nigerian Enterprises Promotion Decree, No. 4 of 1972, generally referred to as the Indigensation Decree to promote indigenous ownership of businesses. The Decree restricted foreign ownership by creating three schedules of enterprises: (i) enterprises exclusively reserved for Nigerians; (ii) enterprises in respect of which foreigners cannot hold more than $40 \%$ of the shares; and (iii) enterprises in respect of which foreigners cannot hold more than $60 \%$. This classification was based on the perceived financial and managerial needs of the country at the time. The second schedule comprised manufacturing companies where foreign participation was expected to bring foreign capital and managerial expertise. The third schedule included capital-intensive enterprises (Ahunwan, 2002).

Presently, the Nigerian Enterprise Promotion Act No. 7 of 1995 has been repealed, thus abolishing any restriction with respect to the limits of shareholding. A foreigner can now fully own a business in Nigeria outside the production of arms and ammunition, drugs and psychotropic substances) and such a company must be incorporated under CAMA 1990, which is the main legal framework for corporate governance in Nigeria (CAMA 1990).

The impetus for the development of corporate governance system in Nigeria also came through the activities of the Nigerian Securities and Exchange Commission (SEC). In 2001, the SEC set up the Atedo Peterside committee to identify weaknesses in the current corporate governance practices in Nigeria with respect to public companies and make recommendations on the necessary changes therein. A Code of Best Practices for Public companies in Nigeria was adopted (SEC, 2003). The code is voluntary and is designed to entrench good business practices and standards for boards and directors, CEOs, auditors, etc., of listed companies, including banks.

A major development in the history of corporate governance in Nigeria is the recent intervention by the Central Bank of Nigeria (CBN). The incessant collapse experienced in the banking sector due to poor corporate governance and the recent bank consolidation exercise forced the CBN to issue new corporate governance guidelines to all banks operating in the country in February 2006. Known as Central Bank of Nigeria Code for Corporate Governance for Banks in Nigeria Post Consolidation (CBN, 2006), the code seeks to address the issues of poor corporate governance and create a sound banking system in Nigeria. The code introduced more stringent requirements in the area of industry transparency, equity ownership, criteria for the appointment of directors, board structure and composition, accounting and auditing, risk management and financial reporting. The new code according to CBN was developed to complement existing codes in the country, and compliance to it is mandatory for all banks.

In Nigeria, a survey by the SEC reported in a publication in April 2003, showed that corporate governance was at a rudimentary stage, as only $40 \%$ of quoted companies, including banks had recognized codes of corporate governance in place. Specifically for the financial sector, poor corporate governance was identified as one of the major factors in virtually all known instances of financial institutions' distress in the country (CBN, 2006).

The Institute of Directors (IOD) Nigeria, has also contributed to the development of corporate governance in Nigeria. IOD, Nigeria was established in Nigeria in 1983 and became full affiliate in 2003. In 2005, the DOI, Nigeria set up a centre for Corporate Governance to champion the cause of good corporate governance amongst its members. The IOD, Nigeria carries out the corporate governance responsibility through a framework developed by the African Management Services Company (AMSCO). AMSCO is a joint initiative of the United Nations Development Programme (UNDP), African Development Bank and the International Finance Corporation (IFC). One of the objectives for the formation is the promotion of good corporate governance (Molokwu, 2003:82).

The Financial Institution Training Centre (FITC) established 1981 by the Banker's Committee comprising the CBN, Nigerian Deposit Insurance Corporation (NDIC), all licensed banks and discount houses in Nigeria, has contributed significantly to the development of corporate governance in the 
country. One of its objectives is "to protect, promote and advance the knowledge of good corporate governance in all sectors of the Nigerian economy" (FITC, n.d.). Over the years it organizes series of seminars and roundtables to create the needed awareness, and sensitize the stakeholders on the importance of good corporate governance to organisational survival. Arising from these activities, is the publication by FITC - Issues in Corporate Governance (Alo, 2003), which today stands as a major contribution to corporate governance literature and a reference point in corporate governance discourse in Nigeria.

The Society for Corporate Governance Nigeria (SCGN) established on March 31, 2005 is equally making significant contributions to the evolving corporate governance system in Nigeria. The SCGN's major objective is to promote the practice of corporate governance by directors and officers of companies with a view to optimizing shareholder value (SCGN, 2005). The promotion of good corporate governance practices will provide an important framework for a timely response by a company's board of directors to situations that may directly affect shareholders' value.

Having presented the nascent history of corporate governance in Nigeria, the next section addresses the issues of corporate governance practices entrenched in the country's regulatory framework.

\section{Legal and Regulatory Framework of Corporate Governance}

As noted above, the observance of the principles of good corporate governance in Nigeria has been secured through a combination of voluntary and mandatory mechanisms. The SEC Code of Best Practice for Public Companies in Nigeria is voluntary and is designed to entrench good business practices and standards for all listed companies, including banks. The mandatory corporate governance provisions relating to banks are contained in the Companies and Allied Matters Act (CAMA) 1990, the Banks and other Financial Institutions Act (BOFIA) 1999, the Investments and Securities Act 1999. The Securities and Exchange Commission Act (SECA) 1988 (and its accompanying Rules and Regulations, the Code of Conduct for Directors of Licensed Banks and Financial Institutions (approved by the Bankers' Committee in 2003) and Code of Corporate Governance for Banks in Nigeria Post Consolidation issued by CBN in 2006. Compliance with the provisions of these codes is compulsory.

These different institutions are saddled with the responsibility of ensuring effective management, control and accountability of public companies in Nigeria. It is pertinent to discuss the respective roles of these institutions.

\section{The Role of the Government}

The government plays a key role in corporate governance, by providing the legal framework for company incorporation, defining the parameters of business activities, monitoring their operations to conform with established standards and meeting obligations to all stakeholders and the society at large. The underlying principles which are embedded in the statute concerning the management and control of business enterprises in Nigeria, according to Okike (2007:176) are:

- the recognition of a company as a legal entity, distinct from its owners;

- the unlimited life of a company, because of the transferability of shares;

- an elected board oversees the running of the company and is accountable to the members on their stewardship;

- the directors have a responsibility to keep proper records of company's financial affairs, and to make appropriate returns;

- independent auditors are appointed by the members, to report on the truth and fairness of financial statements prepared by management.

The main legal framework for corporate governance is CAMA 1990, which governs company law in Nigeria. There are three principal mediums for doing business in the country. An individual operating as sole proprietor without formality, a partnership of two or more persons and the formation of a limited liability company registered under CAMA. CAMA places enormous responsibilities in the hands of 
board members, to effectively manage and control the affairs of the company to ensure corporate accountability, transparency and responsibility to shareholders and stakeholders. One of the government's agencies set up to monitor CAMA is the Corporate Affairs Commission (CAC).

\section{The Role of the Corporate Affairs Commission (CAC)}

The CAC was established as an autonomous body to replace the Companies Registry, a department of the Federal Ministry of Commerce and Tourism, which was then responsible for the registration and administration of the repealed Companies Act 1968. Section I of the CAMA 1990 establishes the CAC and charged it with the responsibility of overseeing the regulation and supervision of the formation, incorporation, registration, management and winding up of companies. The CAC maintains register of companies in all the states of the federation and undertakes investigations into the affairs of any company if the interests of shareholders and the public so demand. All companies are required to submit their audited financial statements to the CAC within 42 days of the annual general meeting. The Registrar of Companies at the CAC monitors compliance with the requirements of the Act, for noncompliance by companies and their officers. The role performed by the $\mathrm{CAC}$ increases confidence in the business community and provides protection for the individual consumer, creditor, or shareholders. Okike (2007) however, notes that in practice, the role of the CAC has remained perfunctory and ineffective as some companies and even auditors are known to have flouted company legislation without being punished. There is apparent general weakness in the enforcement mechanism of the CAC, due essentially to corrupt practices and poor record management.

\section{The Role of the Securities and Exchange Commission (SEC)}

The SEC is the apex regulatory organ of the capital market. The SEC was established by Decree No. 71 of 1979 , but took effect retrospectively from $1^{\text {st }}$ April 1978. Its primary objective is the promotion of an orderly and active capital market. A series of reviews in the country's capital market and financial system led to the promulgation of the Investment and Securities Decree No. 45 of 1999. The main objective of the Act was to create a conductive investment climate and to attract foreign investors into the country. SEC has the major functions of ensuring adequate protection of securities and the registration of all securities dealers, investment advisers and physical markets, such as the stock exchange and their trading floors/branches, in order to maintain proper standards of conduct and professionalism in the securities business. It regulates the securities market participants under the Investment and Securities Act of 1999 and the Securities and Exchange Commission Rules and Regulation 1999.

In keeping with its mandate of propagating good corporate governance, the SEC introduced the Code of Best Practices for Public Companies in Nigeria (SEC, 2003). This code is aimed primarily at ensuring that managers and investors of companies carry out their duties within a framework of accountability and transparency. The code focuses on the following key areas: (i) the board of directors; its responsibilities, structure and procedures (ii) audit committee and (iii) shareholders rights and privileges. A brief description of their functions and responsibilities are presented here.

\section{The Boards of Directors}

The Code provides for the responsibilities and functions of the board. The board has the responsibilities of directing the affairs of a company in a lawful and efficient manner and to ensure that the company continues to improve its value creation. The code lists the specific functions of the board to include: strategic planning; selection, performance appraisal and compensation of senior executives; succession planning; communication with shareholders; ensuring the integrity of financial controls and reports; and ensuring that ethical standards are maintained and that the company complies with the laws of Nigeria. The Code recommends a board size of not more than 15 and not less than 5 with a mix of executive and non-executive directors. 


\section{Audit Committee}

The Code recognizes the importance of the Audit Committee because of its place in ensuring an objective of raising corporate governance standards in the organisation. The recommendations of the Audit Committee are designed to supplement the provisions of section 359(6) the CAMA. Thus, the responsibilities of the Audit Committee are to:

a. ascertain whether the accounting and reporting policies of the company are in accordance with legal requirements and agreed ethical practices;

b. review the scope and planning of audit requirement;

a. c review the findings on management matters in conjunction with the external auditor and department responses thereon;

c. keep under review the effectiveness of the company's system of accounting and internal control;

d. make recommendations to the Board in regard to the appointment, removal and remuneration of the external auditors of the company; and

e. authorize the internal auditor to carry out investigations into any activities of the company which may be of interest or concern to the committee.

\section{Shareholders}

The Codes makes a number of recommendations to facilitate the participation of shareholders at general meetings. In this regard, a general meeting's venue should be such that it is possible and affordable, cost and distance wise, to enable a majority of shareholders to attend and vote, so as not to disenfranchise them.

The Code requires enough notice of such meetings to be given to shareholders. Thus, the notices of meetings should be sent at least 21 working days before the meeting with such details (including annual reports and audited financial statements) and other information as will enable them to vote properly on any issue. The general meeting should become an opportunity for the board of a company to communicate with the shareholders and to encourage shareholder participation in the governance of the company.

\section{The Role of Central Bank of Nigeria (CBN)}

The $\mathrm{CBN}$ is the apex regulatory institution in the banking industry. It promotes monetary stability and a sound financial system, acts as banker and financial adviser to the Federal Government as well as bank of last resort to other banks. The powers of the CBN include the regulation and supervision of the operations of banks and application of sanctions against defaulting banks and the revocation of licences, where necessary. The CBN has been very insistent on standards particularly regarding persons who are appointed Chairmen, members of the board of directors and top management of banks. The CBN released a Code on Corporate Governance for Banks on March $1^{\text {st }} 2006$ (effective April 3, 2006), after the bank consolidation exercise. This was essentially to address the issue of poor corporate governance in the banking sector.

The CBN code which has the force of law, prescribes a minimum standard which individual banks must meet. All existing banks in country are required by the code to adopt and enforce well articulated codes of ethics and conduct for directors, management and staff and to render periodic reports (Templars, 2006).

The key highlights of the Codes of corporate governance of SEC and CBN include:

- Separating the roles of the CEO and the board Chairman;

- Prescription of non-executive and executive directors on the board;

- Improving the quality and performance of board membership;

- Introducing merit as criteria to hold top management positions;

- Introducing transparency, due process and disclosure requirements; 
- Transparency on financial and non-financial reporting;

- Protection of shareholder rights and privileges; and

- Defining the composition, role and duties of the audit committee, etc (Wilson, 2006).

The strategic position of the banking industry in the economy of the nation makes it imperative for the CBN to put in place a more stringent code of good corporate governance for banks. This is because bank failures due to poor corporate governance "can pose significant public costs and consequences due to their impact on any applicable deposit insurance systems and the possibility of broader macroeconomic implications, such as contagion risk and impact on payment systems [and also] can lead markets to lose confidence in the ability of a bank to properly manage its assets and liabilities, including deposits, which could in turn trigger a bank run or liquidity crisis" (Wilson, 2006:3).

\section{Challenges facing Corporate Governance in Nigeria}

The challenges of corporate governance in Nigeria are quite enormous especially considering the development in the banking industry. Before the consolidation exercise of 2006, the Nigerian banks were very weak with poor corporate governance, and this affected customers' confidence in banking operations. The consolidation exercise helped to reduce the total number of banks from 89 to 25 mega banks - through mergers and acquisitions and consolidations. This development posed serious challenges which the CBN has acknowledged in its Code of Corporate Governance (CBN, 2006). These challenges include.

- Technical incompetence of board and management,

- Boardroom squabbles among directors;

- Squabbles among staff and management;

- Very few banks have a robust risk management system;

- Malpractices and sharp practices;

- Insider abuses;

- Rendering false returns and concealment of information from examiners;

- Ineffectiveness of board/statutory committees;

- Inadequate operational and financial controls, etc.

The CBN Code, in fact, seeks to address these major challenges and develop a sound banking system in the country. Some have argued that the Code "may be unable to accomplish this if the underlying legal, institutional and regulatory frameworks for corporate governance in Nigeria are weak, inefficient and inadequate" (Wilson, 2006:4). The CBN is apparently overburdened in its role as a bankers' bank, responsible for policy formulation and banking supervision. The additional responsibility of monitoring for compliance to the code of corporate governance may not be effectively handled. The capacity of the $\mathrm{CBN}$ to offer regulatory oversight of the banking and financial sector needs to be strengthened.

The code of best practice (SEC, 2003) has commendable recommendations designed to enhance the development of corporate governance in the country. This code is voluntary and therefore selfcompliance by companies is always problematic. According to Nmehielle and Nwauche (2004:49) "the minimum that can be done is to make it mandatory for all these companies to show compliance with the code either in their annual returns to corporate Affairs Commission or in the Annual General Meeting of the companies or make compliance part of the listing requirements of the Nigerian Stock Exchange". While it is acknowledged that the institutions and the legal framework for effective corporate governance appear to be in existence in the country, the compliance and/or enforcement appear to be weak or non-existence. Oyejide and Soyibo (2001) suggest that for Nigeria to reap the benefits of effective corporate governance there is need to strengthen the enforcement mechanism of the regulatory institutions. The roles of the courts are important in this regards. The judicial system must have the capacity to restore the confidence of the shareholder and help him to enforce his rights. 
The CAC must improve on its enforcement mechanisms, put in place more effective monitoring strategies and develop mechanisms to eliminate corrupt practices in the Commission. The CAC has the powers to receive annual returns from companies to know the state of affairs of such companies and identify areas the companies have failed in their responsibilities. The creditable discharge of these functions by CAC will definitely ensure the entrenchment of good corporate governance. There is need for CAC to be restructured to make it independent and able to ensure that the provisions of the CAMA 1990 are effectively enforced. At present, the CAC is deeply concerned with the registration of companies, while the monitoring and compliance activities are very weak. The challenge is for CAC to do more and prosecute companies that commit offences that under-mind the principles of good corporate governance.

Deliberate accounting fraud is another serious problem of corporate governance in the country. Cases of "inaccurate reporting and non-compliance with regulatory requirements" (Ibru, 2008) and the "prevailing incidences of false and misleading financial reporting" (Al-Faki, 2007) by some corporate organizations lead to corporate failures. A current case in point is that of Cadbury Nigeria PLC, when in 2006 the company falsified its audited financial statements. The CEO and the directors of the company who were found guilty by SEC that investigated the case were accordingly sanctioned (Onwuamaeze, 2008).

Corporate governance institutions must put in place strong internal control mechanisms to provide checks and balances against the oversight responsibility of the boards. Almost all reported cases of corporate failures indicate some level of failure on the part of directors to properly discharge their oversight functions and ensure that they receive all relevant information and demonstrate good faith judgement (Ahmed, 2007). The internalization of effective mechanisms in the running of corporate organisations would encourage accountability and transparency and also discourage concealment of financial statements. Such internal mechanisms would help establish the concept of insider whistle blowers in form of honest staff of the companies to speak out on questionable practices without repercussions.

An emerging and interesting development in the Nigerian corporate governance is shareholder activism. The shareholders are becoming more proactive in the push for effective corporate governance. "The bounding together of shareholders in Nigeria has come both through private initiatives and government intervention. In a bid to shore up public participation in the ownership of corporation the Nigerian government encouraged and facilitated the establishment of a network of Shareholder Associations", according to (Amao and Amaeshi, 2007:124). The different shareholder associations are registered with CAC. According to Etukudo (2000), the shareholder associations serve the interest of the investing public as shareholders who have the opportunity to contribute to the formulation of broad corporate policies, thereby enhancing management accountability. The challenge is for the corporate governance institutions to strengthen shareholder activism as a prerequisite for effective corporate governance and accountability in Nigeria.

Corporate governance discourse in Nigeria has apparently not been directed at state-owned enterprises (SOEs) despite the fact that there is abundant evidence that these enterprises have the worst abusers of corporate governance principles. Wong (2004) notes in his extensive research of SOEs, that poor corporate governance lies in the heart of the performance of SOEs throughout the world. In Nigeria, there is the general weakness of public institutions, high level of corruption, poor managerial capacity and total absence of market discipline for transparency and accountability, which combine to create a seeming lack of demand for corporate governance in state-owned enterprises (Ahmed, 2007). A major challenge now, is for the corporate governance institutions to extend their activities to state-owned enterprises to help entrench the principles of good corporate governance. State-owned enterprises have a major role to play in the economic development of the nation, and their failure to perform and achieve the goals for which they were established would spell doom for the economy. It is therefore important that good corporate governance code and structure are entrenched in state-owned enterprises. 


\section{Conclusion}

Corporate governance as an emerging subject, concerned with the management and control of companies for the interest of stakeholders and society in general, has attracted more global discourse, generated more debates and a plethora of literature in the USA, Europe and Australia than in Africa generally, and Nigeria in particular. The well-publicised corporate scandals and failures in these nations and the East Asian crises gave impetus for the development of international and national standards on corporate governance. Nigeria, which has her fair share of corporate scandals and failures has joined the global trend to develop the codes of good corporate governance to guide business operations.

The evolution of corporate governance system in Nigeria has a nascent history, with the mainstream issues emerging with the enactment of CAMA 1990. The SEC 2003 Code and the CBN 2006 Code added more impetus in nurturing the national corporate governance system. These codes have tremendous impact on the operations of corporate organisations in the country, and ensuring that transparency, accountability, probity, integrity and fairness are promoted as standards for creating value for shareholders, stakeholders and the general public.

There are legions of challenges facing corporate governance system in the country. Some of these challenges include making the voluntary codes requiring self-compliance mandatory, developing more effective mechanisms for monitoring compliance to the codes, strengthening the enforcement mechanisms of the regulatory institutions, developing strong internal mechanisms to provide checks and balances against the oversight responsibility of the boards, creating the necessary conditions to encourage shareholder activism and extending corporate governance activities to state-owned enterprises where cases of corporate governance abuses are rampant.

\section{References}

Abor, J. (2007) Corporate governance and financial decisions of Ghanaian listed firms, Corporate Governance, 7 (1),83-92.

Abor, J. \& Adjasi, C.K.D. (2007) Corporate governance and the small and medium enterprises sector: theory and implications, Corporate Governance, 7 (2),111-122.

Aguilera. R. V. \& Cuervo-Cazurra, A. (2004) Codes of good governance worldwide, what is the trigger? Organisation Studies, 25 (3), 415-443.

Ahmed. M. (2007) Corporate governance: a new fad or an important development prerequisite? Paper presented at the Management Express Forum of the British Council in Calabar 30 $0^{\text {th }}$ March 2007.

Ahunwan, B. (2002) Corporate governance in Nigeria, Journal of Business Ethics, 37 269-286.

Ajogwu, F. (2007) Corporate governance in Nigeria: law and practice. Lagos: Centre for Commercial Law Development.

Al-Faki, M. (2007) The incidence of inaccurate corporate financial reporting in Nigerian capital market: the role of Securities and Exchange Commission in preventing future occurrences. http://www.sec.gov.ng Accessed 28 September, 2008.

Alo, O. (2003) Issues in corporate governance (ed). Lagos: Financial Institutions Training Centre.

Amao, O. \& Amaeshi, K. (2008) Galvanising shareholders activism: prerequisite for effective corporate governance and accountability in Nigeria. Journal of Business Ethics, 82:119-130.

Bhasa, M. P. (2004) Global corporate governance: debates and challenges, Corporate Governance, 4 (2), 5-17.

Central Bank of Nigeria, CBN (2006) Code of corporate governance for banks in Nigeria post consolidation. http://www.cenbank.org/out/PUBLICATIONS/BSD/2006/CORPGOVPOSTCONSO.PDF. Accessed 30 September, 2008.

Chambers, R. (2006) Corporate secrecy: the final barrier to corporate governance, International Journal of Business Governance and Ethics, 2 (1/2), 43-53.

Claessens, S. \& Bruno, V. G. (2007) Corporate governance and regulation: can there by two much of a good thing? Policy Research Working Paper 4140, March 2007, The Word Bank. 
Commonwealth Association for Corporate Governance (1999) CACG guidelines. Principles for corporate governance in the Commonwealth, Marlborough, New Zealand.

De Cleyn, S. H. (2008) Compliance of companies with corporate governance codes: case study of Listed Belgian SMEs, Journal of Business Systems, Governance and Ethics, 3 (1), 1-16.

Elebute, K. (2000) Corporate governance, reporting and shareholder value, Business and Management Journal, 3 (1), 8-19.

Etukudo, A. (2000) Issues in privatization and restructuring in Sub-Saharan Africa - Interdepartmental Action Programme on Privatization, Restructuring and Economic Democracy Working Paper IPPRED-5 http://www:ilo.org/public/english/employment/ent/papers/ippred5.htm. Accessed 28 September, 2008

Financial Institution Training Centre, FITC (n.d.) Corporate profile. http://www.fitc ngr.com/about fitc\%5Cindex.asp Accessed 12 October, 2008.

Hill, J. (2008) Evolving 'rules of the game' in corporate governance reform, International Journal of Corporate Governance. 1 (1), 28-48.

Ibru, C. (2008) Measuring corporate governance and risk in Africa. Paper presented at the Africa investor Index Summit, New York Stock Exchange, September 15, 2008. http://www.Africainvestor.com/presentations Accessed 12 October, 2008.

Inyang, B. J. (2004) Corporate planning \& policy: concepts and application ( $1^{\mathrm{st}}$ Edition) Calabar, Nigeria; Merb Publishers.

Judge, W.Q., Douglas, T. J. \& Kutan, A. M. (2008) Institutional antecedent of corporate governance legitimacy. Journal of Management, 34 (4), 765-785.

Kay, J. \& Silberston, A. (1995) Corporate Governance, National Institute Economic Review, 153 (1), 84-107.

King Reports on Corporate Governance for South Africa (1994, 2002), Institute of Directors, South Africa

Koufopoulos, D. N. (2006) Corporate governance development. $4^{\text {th }}$ International Conference in Business, Economics, Management and Marketing held at Athens, Greece June 26-28, 2006. http://www.atiner.gr/docs/Corporate\%20Governance.htm Accessed 13 October 2008.

Kyereboah-Coleman, A. (2007) Corporate governance and shareholder value maximization: an African perspective, African Development Review, 19 (2), 350-367.

Malin, C. (2008) Institutional shareholders: their role in the shaping of corporate governance, International Journal of Corporate Governance, 1 (1), 97-105.

Mardjono, A. (2005) A tale of corporate governance: lessons why firms fail, Managerial Auditing Journal, 20 (3), 272-283.

Mason, C., Kirkbride, J. \& Bryde, D. (2007) From stakeholders to institutions: The changing face of social enterprise governance theory. Management Decision, 45 (2), 284-301.

Molokwu, B.S. (2003) Building an appropriate framework for corporate governance. In O. Alo (ed) Issues in corporate governance (pp.71-85) Lagos: Financial Institute Training Centre.

Muranda, Z. (2006) Financial distress and corporate governance in Zimbabwean banks, Corporate Governance, 6, (5), 643-654.

Nmehielle, V. O. \& Nwauche, E. S. (2004) External-internal standards in corporate governance in Nigeria. Paper presented at the Conference on Corporate Governance and Accountability in SubSaharan Africa. The George Washington University Law School. Public law and Legal Theory Working Paper No. 115, October 29, 2004. http://www.ssrn.com/abstract=627664 Accessed 8 October, 2008.

OECD (1999) Principles of corporate governance, Paris: OECD Publication Services.

OECD (1999) Principles of corporate governance, Paris: OCED Publication Services.

Ogbechie, C. \& Koufopoulos, D. N. (2007) Corporate governance practices in publicly quoted companies in Nigeria, International Journal of Business Governance and Ethics, 3 (4), 350-381.

Okeahalam, C. C. \& Akinboade, O. A. (2003) A review of corporate governance in Africa: literature, issues and challenges. Paper prepared for the Global Corporate Governance Forum, 15 June 2003. pp 1-34. http://www.ifc.org. Accessed 05 October 2008. 
Okike, E. N. M. (1994) Curious auditing regulations in Nigeria: a case study of cultural/political influences on auditing practices, The International Journal of Accounting. 29, 78-91.

Okike, E. N. M. (1995) Corporate audit reporting and the structure of the market for audit services to listed companies in Nigeria: a longitudinal study. A Research Report submitted to the Research Committee of the Institute of Chartered Accountants of Nigeria (ICAN).

Okike, E. N. M. (1998) Voluntary disclosures in corporate audit reports: a Nigerian case study (19781989), International Journal of Auditing, 2, 139-166.

Okike, E. N. M. (1999) A longitudinal analysis of the quality of audit reporting on the accounts of listed companies in Nigeria following the indigenisation of equity capital (1978-1989), Research in Accounting in Emerging Economies, Supplement 1, 255-286.

Okike, E. N. M. (2007) Corporate governance in Nigeria: the status quo, Corporate Governance, 15 (2), 173-193.

Olusa, M. (2007) Corporate governance vs. Cadbury Nigeria, http://www.guardiannewsngr.com/editorial opinion/article 03/160107. Accessed 10 October, 2008.

Onwuamaeze, D. (2008) Cadbury's fraudulent directors punished. Newswatch Magazine (Nigeria), April 28, 2008, pp. 58-59.

Oyejide, T. A. \& Soyibo, A. (2001) Corporate governance in Nigeria. Paper presented at the Conference on Corporate Governance, Accra, Ghana, 29-30 January, 2001. http://www.cipe.org/about/news/conference/africa/ghana/pdf/CorpGov/Nigeria.pdf Accessed 28 September 2008.

Reddy, P. L. S. (2001) Corporate governance - emerging trends. CFCG guidelines on corporate governance (Centre for Corporate Governance of Institute of Directors India) p.5-3 http://www.wcfg.net/guide.pdg. Accessed 13 October, 2008.

Rossouw, G. J. (2005) Business ethics and corporate governance in Africa, Business \& Society, 44 $(10,94-106$.

Scott, D. H. (2007) Strengthening the governance and performance of state-owned financial institutions, Policy Research Working Paper 4321, August 2007, The World Bank.

Securities and Exchange Commission (SEC) of Nigeria (2003) Code of corporate governance in Nigeria. http://www.sec.gov.ng/pdf/Corporate\%Governance\%2Ditd.pdf. Accessed 10 October, 2008.

Society for Corporate Governance Nigeria, SCGN (2005). About us. http://www.corporategovernancenigeria.org/about us.php. Accessed 12 October, 2008.

Subramanaya, S. 2007, Corporate governance - beyond the scandals and buzzwords. http://www.media.wiley.com/product data/excerpt/76/04707541/0470754176.pdf. Accessed 15 October 2008

Templars Barristers \& Solicitors (2006) Corporate governance - new corporate mantra? http://www.templars-law.com. Accessed 13 October, 2008

The Companies and Allied Matters Act. 1990. CAMA 1990. http://www.Nigeria law.org. Accessed 13 October, 2008.

Vinten, G. (1998) Corporate governance: an international state of the art. Managerial Auditing Journal, 13 (7). 419-431.

Vinten, G. (2002) The corporate governance lessons of Enron, Corporate Governance, 2 (4), 4-9.

Wieland, J. (2005). Corporate Governance, values management, and standards: a European perspective, Business \& Society, 44 (1), 74-93.

Wilson, I. (2006) Regulatory and institutional challenges of corporate governance in Nigeria post banking consolidation. Nigerian Economic Summit Group (NESG) Economic Indicators, April June 2006, 12 (2),1-10. http://www.templars-law.com/upload/NESG\%Corp\%20Gov\%20Paper.pdf

Wong, S. C. Y. (2004) Improving corporate governance in SOEs: An international approach, Corporate Governance International, 7(2), 5-15

Yakasai, A. G. A. (2001) Corporate governance in a third world country with particular reference to Nigeria, Corporate Governance, 9 (3), 238-253. 
